\title{
Impact of a program aimed at reducing catheter-related infections implemented in nine pediatric intensive care units in Argentina
}

\author{
Ana M. Lenz, M.D. ${ }^{a}$, Elena Andion, B.S. ${ }^{a}$, Silvina Ruvinsky, M.D. ${ }^{a}$, \\ Clarisa Aguirre, M.D. ${ }^{b}$, Julieta Álvarez Parma, M.D. ${ }^{c}$, Facundo Jorro, M.D. ${ }^{d}$, \\ Gabriela López Cruz, M.D. ${ }^{e}$, Martín Pascutto, M.D. ${ }^{a}$, Matías Penazzi, M.D.f, \\ Silvia Santos, M.D. ${ }^{g}$, Marcela Zuázaga, M.D. ${ }^{a}$, Norma Aquino, B.S. ${ }^{a}$, \\ Juan C. Vassallo, M.D. ${ }^{a}$, Guillermo Moreno, M.D. ${ }^{a}$, Ricardo Magliola, M.D. ${ }^{a}$, \\ Aldo Haimovich, M.D. ${ }^{a}$, Luis Landry, M.D. ${ }^{a}$ and Rosa Bologna, M.D. ${ }^{a}$
}

\section{ABSTRACT}

Catheter-related infections (CRIs) cause a high level of morbidity and mortality with the increasing use of hospital resources.

Objective. To describe the outcomes of a program implemented to reduce the rate of CRIs in pediatric intensive care units in Argentina.

Population and methods. Collaborative, multicenter, clinical-epidemiological, quasiexperimental, before-and-after intervention study. Children who had a central venous catheter during hospitalization in 9 pediatric intensive care units in the Autonomous City of Buenos Aires, Greater Buenos Aires, and other provinces between June 2011 and April 2012 were included. A bundle of measures based on health care staff training on catheter insertion, hand hygiene, and checklists was put into practice and implemented measures were monitored. The number and annual rate of CRIs and the rate of central venous catheter use before and after the program implementation were compared (Stata 8.0).

Results. The total number of CRIs was 117 and 74 before and after the intervention, respectively. The rate of CRIs was 8.6/1000 days of central venous catheter use and 5.8/1000 days before and after the intervention, respectively; RR: 0.82 (95\% confidence interval: $0.68-0.98$ ), $\mathrm{p}=0.015$. The rate of central venous catheter use decreased from $54 \%$ to $49 \%$, a non-significant difference. Conclusions. The program achieved a significant reduction in CRI rates. Based on the program, CRI surveillance was implemented in all participating pediatric intensive care units. Training and continuous surveillance are necessary to maintain and improve the outcomes accomplished with the program.

Key words: catheter-related infections, central venous catheters, pediatric intensive care units.

http: / / dx.doi.org/10.5546/ aap.2018.eng.93

To cite: Lenz AM, Andion E, Ruvinsky S, et al. Impact of a program aimed at reducing catheter-related infections implemented in nine pediatric intensive care units in Argentina. Arch Argent Pediatr 2018;116(2):9397.

\section{INTRODUCTION}

Intravascular catheters are safe devices routinely used in critical patients because they enable the administration of inotropes, highdose drugs, and blood products, and help with hemodynamic monitoring. Unfortunately, their use is not without risks, especially in young children, who usually meet all risk factor criteria. Bloodstream infections associated with central venous catheters (CVCs) are a significant health problem; they account for an increased morbidity and mortality in the pediatric intensive care unit, extending the length of stay from 10 to 40 days and, thus, health care-related costs. CVC use is one of the most common causes of hospital-acquired bacteremia, which ranges from 4 to 8 infections per 1000 catheter days or from $1 \%$ to $13 \%$, with a higher rate of infection in the most commonly used sites. ${ }^{1-3}$ Catheter-related infections (CRIs) should be considered a patients' safety concern. The systematic implementation of a series of interventions as part of a Program for the Prevention of Catheter-Related Infections $\mathrm{s}^{4,5}$ in pediatric intensive care units (PICUs) (MultiCOMBO) has therefore become a strategy aimed at improving health care quality. ${ }^{6}$ These "MultiCOMBO" programs are bundles of measures that are implemented together in order to accomplish the intended outcome, because it has been observed that interventions with a high level of impact and evidence that have been implemented separately 
have failed to reduce the rate of infections. ${ }^{7}$ This systematic intervention has been successfully put into practice in many hospitals worldwide. ${ }^{6,8}$

The proposal is to implement a multidisciplinary bundle of simple measures with a high level of evidence ${ }^{9}$ and with recognized impact to effectively reduce CRIs. Significant among these measures are health care staff training ${ }^{10}$ and the introduction of new monitoring and information feedback techniques. ${ }^{11-13}$

In the 2008-2009 period, the incidence of CRIs at the PICUs of Hospital Garrahan ranged from 9 to 12 per 1000 CVC days. ${ }^{14,15}$ The Multidisciplinary Program for the Prevention of Catheter-Related Infections was first implemented in July 2010 and resulted in a reduction of the CRI rate to 5.7 per $1000 \mathrm{CVC}$ days. ${ }^{16}$ Considering that this problem is common to all PICUs, it was proposed to extend the program to other PICUs across Argentina to disseminate health care quality improvement processes and optimize health care provision.

The objective of this study was to compare the incidence of CRIs before and after the implementation of a bundle of measures designed to this end at each participating PICU.

\section{PATIENTS AND METHODS}

This was a multicenter study with a beforeand-after, quasi-experimental design that assessed the impact on the incidence of CRIs before and after the implementation of a bundle of measures aimed at reducing CRIs.

Argentina has 132 PICUs, 24\% of which are located in public hospitals. PICUs were selected from public hospitals based on their prior participation in a quality improvement program that had been implemented within 3 years earlier and their compliance with implementation and recording feasibility requirements, as well as on the approval from jurisdictional authorities and health care providers responsible for the unit.

A total of 9 PICUs from 7 hospitals participated: Hospital de Pediatría "Juan P. Garrahan," Hospital General de Niños "Pedro de Elizalde," Hospital de Niños de San Justo, Hospital Regional de Agudos "Eva Perón" (formerly Castex), Hospital Interzonal de Niños "Eva Perón" from Catamarca, Hospital Pediátrico "Juan Pablo II" from Corrientes, and Provincial Center of Pediatric Health (Centro Provincial de Salud Infantil, CEPSI) "Eva Perón" from Santiago del Estero. The protocol was approved by the Research Committee of Hospital Garrahan (coordinating site for the multicenter study) and the research committees of each participating hospital. The informed consent was not requested because interventions done on patients are not different from everyday practice.

All children who had a CVC during hospitalization in the PICU of a participating hospital between June $1^{\text {st }}, 2011$ and April $30^{\text {th }}, 2012$ were included. The following outcome measures were recorded: CRI rate per 1000 CVC days as defined by the epidemiological surveillance of the Centers for Disease Control and Prevention (CDC) (see definitions in Annex 1), CVC use rate, adherence to hand washing (Annex 2 ), and adherence to CVC insertion control (Annex 3). To assess the program's effectiveness, the preintervention period was defined as that between August 1 $1^{\text {st }}, 2010$ and May 31 $1^{\text {st }}, 2011$ and the postintervention period was that between June $1^{\text {st }}$, 2011 and March 31 ${ }^{\text {st }}, 2012$.

Monthly workshops were carried out on hand hygiene and the implementation of the five moments at the point of patient care and on the prevention of hospital-acquired infections inside the PICU. Progress and outcomes were shared with all health care staff members on a monthly basis. Through personal meetings with the execution team and virtual meetings with the participating sites, potential solutions were discussed and agreed upon and doubts were cleared as they appeared during the program implementation. The referral and counter-referral system currently valid at Hospital Garrahan was used in the framework of the Subprogram for Teaching-Health Care Collaboration with the PICUs of CEPSI from Santiago del Estero and the "Eva Perón" hospital from Catamarca.

Annex 4 describes the program and the implementation stages at the different participating sites.

\section{Statistical analysis}

In this study, dependent outcome measures were identified as indicators of interventions (CVC use rate, CRI rate per 1000 catheter days, percentage of CRIs, absolute number of CRIs, percentage of adherence to measures [globally or disaggregated by bundle]), considering the intervention in the bundle of measures as a whole and comparing selected indicators before and after the intervention. Continuous outcome measures were summarized using position and dispersion measures as per distribution; categorical data were described using frequency tables and charts. The bivariate analysis of outcome measures was done 
using the $\mathrm{t}$ test, the Wilcoxon test or the $\chi^{2}$ test, as applicable. The significance level was established at $<0.05$ and the statistical package for data processing was Stata 8.0.

\section{RESULTS}

Table 1 details the data collected from each participating PICU before the intervention. Table 2 shows the impact of the program in the reduction of the number of CVC-related infections, the rate of catheter use, and the rate of CVC-related infections. At the PICUs from the hospitals that started their first year of the program, a significant reduction was observed in the rate of CRIs, together with a reduction in the total number of CRIs compared to the year prior the program implementation. This was not observed at the 3 PICUs from the coordinating site that had started the program 1 year before, where rates remained stable. The total number

TABLE 1. Baseline characteristics of each participating pediatric intensive care unit in the pre-intervention period

\begin{tabular}{lcccccc}
\hline PICU & Capacity & $\begin{array}{c}\text { Mortality } \\
\%\end{array}$ & $\begin{array}{c}\text { Occupancy } \\
\%\end{array}$ & $\begin{array}{c}\text { No. of } \\
\text { patients/day }\end{array}$ & $\begin{array}{c}\text { No. of CVC } \\
\text { days }\end{array}$ & $\begin{array}{c}\text { Rate of CVC } \\
\text { use/100 }\end{array}$ \\
\hline PICU 1 & 15 beds & 15 & ND & 2667 & 590 & 22.12 \\
bacteremia/1000
\end{tabular}

PICU: pediatric intensive care unit; CVC: central venous catheter; ND: no data.

TABLE 2. Analysis of program impact before and after the intervention

\begin{tabular}{|c|c|c|c|c|}
\hline & & Pre-intervention & Post-intervention & $\mathbf{P}$ \\
\hline PICU 1 & $\begin{array}{l}\text { No. of CRI events } \\
\text { Rate of CVC use } \\
\text { Rate of CRI x } 1000 \text { days }\end{array}$ & $\begin{array}{c}13 \\
22.12 \% \\
22\end{array}$ & $\begin{array}{c}6 \\
22.87 \% \\
10.13\end{array}$ & $\begin{array}{c}\mathrm{P}=0.5 \\
\mathrm{NS} \\
\mathrm{P}=0.16 \mathrm{RR}=0.63(95 \% \mathrm{CI}: 0.32-1.1)\end{array}$ \\
\hline PICU 2 & $\begin{array}{l}\text { No. of CRI events } \\
\text { Rate of CVC use } \\
\text { Rate of CRI x } 1000 \text { days }\end{array}$ & $\begin{array}{c}28 \\
60 \% \\
18.54\end{array}$ & $\begin{array}{c}6 \\
52 \% \\
4.89\end{array}$ & $\begin{array}{c}\mathrm{P}=0.015 \\
\mathrm{NS} \\
\mathrm{P}=0.001 \mathrm{RR}=0.39(95 \% \mathrm{CI}: 0.19-0.81)\end{array}$ \\
\hline PICU 3 & $\begin{array}{l}\text { No. of CRI events } \\
\text { Rate of CVC use } \\
\text { Rate of CRI x } 1000 \text { days }\end{array}$ & $\begin{array}{c}5 \\
42 \% \\
6.95 / 1000\end{array}$ & $\begin{array}{c}3 \\
37.8 \% \\
3.2\end{array}$ & $\begin{array}{c}\mathrm{P}=0.015 \\
\mathrm{NS} \\
\mathrm{P}=0.31 \mathrm{RR}=0.67(95 \% \mathrm{CI}: 0.27-1.64)\end{array}$ \\
\hline PICU 4 & $\begin{array}{l}\text { No. of CRI events } \\
\text { Rate of CVC use } \\
\text { Rate of CRI x } 1000 \text { days }\end{array}$ & $\begin{array}{c}9 \\
54.5 \% \\
9.45 / 1000\end{array}$ & $\begin{array}{c}1 \\
49 \% \\
0.9\end{array}$ & $\begin{array}{c}\mathrm{P}=0.06 \\
\mathrm{NS} \\
\mathrm{P}=0.007 \mathrm{RR}=0.19(95 \% \mathrm{CI}: 0.03-0.67)\end{array}$ \\
\hline PICU 5 & $\begin{array}{l}\text { No. of CRI events } \\
\text { Rate of CVC use } \\
\text { Rate of CRI x } 1000 \text { days }\end{array}$ & $\begin{array}{c}25 \\
61.6 \% \\
13.6 / 1000\end{array}$ & $\begin{array}{c}6 \\
64 \% \\
3.76\end{array}$ & $\begin{array}{c}\mathrm{P}=0.05 \\
\mathrm{NS} \\
\mathrm{P}=0.004 \mathrm{RR}=0.41(95 \% \mathrm{CI}: 0.20-0.85)\end{array}$ \\
\hline PICU 6 & $\begin{array}{l}\text { No. of CRI events } \\
\text { Rate of CVC use } \\
\text { Rate of CRI x } 1000 \text { days }\end{array}$ & $\begin{array}{c}8 \\
15.7 \% \\
30.53 / 1000\end{array}$ & $\begin{array}{c}3 \\
37.6 \% \\
8.28\end{array}$ & $\begin{array}{c}\mathrm{P}=0.45 \\
\mathrm{P}<0.001 \mathrm{RR}=1.54(95 \% \mathrm{CI}: 1.40-1.66) \\
\mathrm{P}=0.06 \mathrm{RR}=0.47(95 \% \mathrm{CI}: 0.18-1.23)\end{array}$ \\
\hline PICU 7 & $\begin{array}{l}\text { No. of CRI events } \\
\text { Rate of CVC use } \\
\text { Rate of CRI x } 1000 \text { days }\end{array}$ & $\begin{array}{c}18 \\
53 \% \\
6.56 / 1000\end{array}$ & $\begin{array}{c}18 \\
39 \% \\
8.26\end{array}$ & $\begin{array}{c}\mathrm{P}=0.72 \\
\mathrm{P}<0.001 \mathrm{RR}=0.60(95 \% \mathrm{CI}: 0.55-0.65) \\
\text { NS }\end{array}$ \\
\hline PICU 8 & $\begin{array}{l}\text { No. of CRI events } \\
\text { Rate of CVC use } \\
\text { Rate of CRI x } 1000 \text { days }\end{array}$ & $\begin{array}{c}18 \\
61 \% \\
6.50 / 1000\end{array}$ & $\begin{array}{c}16 \\
70.38 \\
8\end{array}$ & $\begin{array}{c}\mathrm{P}=0.34 \\
\mathrm{NS} \\
\mathrm{NS}\end{array}$ \\
\hline PICU 9 & $\begin{array}{l}\text { No. of CRI events } \\
\text { Rate of CVC use } \\
\text { Rate of CRI x } 1000 \text { days }\end{array}$ & $\begin{array}{c}11 \\
57 \% \\
5 / 1000\end{array}$ & $\begin{array}{c}15 \\
54 \% \\
6.45 / 1000\end{array}$ & $\begin{array}{c}\mathrm{P}=0.68 \\
\mathrm{NS} \\
\mathrm{NS}\end{array}$ \\
\hline
\end{tabular}

PICU: pediatric intensive care unit; CVC: central venous catheter; CRI: catheter-related infection; NS: non-significant; $\mathrm{CI}$ : confidence interval; RR: relative risk; P: significance. 
of CRIs was 117 and 74 before and after the intervention, respectively (see Table 2), and the total rate of CRIs was 8.6 per 1000 CVC days and 5.78 per 1000 CVC days before and after the intervention, respectively; RR: $0.82(95 \%$ confidence interval [CI]: 0.68-0.98), $\mathrm{p}=0.015$. The rate of CVC use decreased from $54 \%$ to $49 \%$. Only 5 PICUs reported data on adherence to hand hygiene, so the analysis of this outcome measure was not considered useful.

\section{DISCUSSION}

The importance of this multicenter study was that it demonstrated that the implementation of programs aimed at reducing the rate of hospitalacquired infections accomplished significant outcomes based on simple measures available for health care staff. The foundation of these outcomes lies in the extent of involvement of the institution to carry out the program, ongoing education, a change in behavior, and awareness that it is not necessary to have better technology to achieve successful results. It is worth noting that all staff members involved in patient care participated in the program, including technicians and cleaning staff, not only physicians and nurses. In addition, it is necessary to strictly monitor the outcomes using statistics, as well as to compare them over time within the hospital and, in turn, against national and international epidemiological surveillance organizations. ${ }^{15,17}$

Health care staff training on the prevention of hospital-acquired infections started gaining importance more than a decade ago. Coopersmith et al., in $2002,{ }^{10}$ achieved a $66 \%$ reduction in CRIs (from 10.8 to 3.7 ); their study included a pre- and post-test for nurses from an adult ICU on infection prevention knowledge; then, they were given a 10-page document on the topic and received training at the ICU. Berenholtz et al., in 2004, ${ }^{7}$ complemented training with a catheter insertion checklist, and authorized nurses to interrupt the procedure in case of antisepsis breakdown and to do a daily assessment of patient's ongoing $\mathrm{CVC}$ requirement. This group reduced the rate of infections from $11.5 / 1000$ to $0 / 1000$ catheter days, thus demonstrating the great impact of implementing several evidence-based measures at the same time. In this study, Berenholtz included a control group at a different surgical care unit, where the only intervention was training health care staff without any other control measure. The rate of infections was reduced by $75 \%$, compared to the group that introduced several measures at the same time, which achieve a $100 \%$ reduction. ${ }^{7}$ These bundles of measures were replicated in many sites with adequate outcomes and achieved a reduction in hospital-acquired infections. ${ }^{18,19}$

Most sites in the program lacked an active surveillance system to record hospital-acquired infections at the different PICUs, so staff was trained on how to record data and prepare statistics. The implementation of hand washing and catheter insertion checklists basically had an educational impact and allowed to provide training on the good practices for hospitalacquired infections.

One of the most important contributions of this program was starting an active hospitalacquired infection surveillance system, initially for CVC-related bacteremias, one of the most common diseases in the pediatric population.

In the post-intervention period, it was observed that the 6 sites that started their first year in the program achieved a reduction in the number of CRIs, together with a reduction in the rate of CVC use, which meant that, probably, at this point, some sites accomplished a greater level of monitoring of patient $\mathrm{CVC}$ requirement beyond what was strictly necessary. In addition, very high reductions were observed in the rate of CRIs. In some cases, such reduction was statistically significant; in others, the significance showed a trend but as a consequence of a reduction in CVC days, the numerator was probably overestimated and thus, the result of this rate did not achieve the expected statistical significance.

In the 3 PICUs from the coordinating site, a reduction of approximately $50 \%$ had been observed in the first year of the program (2010). ${ }^{14,16}$ This study (2011) did not find a reduction from baseline but stable rates. However, it is worth considering that the study corresponded to the second year of the program in that site so there was probably resistance against implemented measures or a lower level of adherence by health care staff. It has been described that when surveillance and strategies to maintain such measures reduce, adherence decreases and the rate of infections rises again. ${ }^{20-22}$ The high staff turnover, frequent in critical care units, adds to the difficulties of this collective challenge and calls for searching new ongoing encouraging strategies in order to achieve a greater level of adherence. The main change consists in accomplishing changes in the culture of health care staff on the importance of hand hygiene and compliance with all program moments by all 
members so as to achieve a sustained reduction in hospital-acquired infections and continue reducing current CRI rates.

One of the limitations of this study was that it was not a controlled clinical trial but had a beforeand-after design.

It has been considered that the evidence of the program outcomes is sufficient to continue its implementation and replication in the different PICUs of Argentina.

\section{CONCLUSION}

The implementation of this program accomplished a statistically significant reduction in the rate of CVC-related bacteremia among children hospitalized in the PICU.

\section{REFERENCES}

1. O'Grady N. Alexander M, Dellinger E, et al. Guidelines for the Prevention of Intravascular Catheter-Related Infections. The Hospital Infection Control Practices Advisory Committee, Center for Disease Control and Prevention, U.S. Pediatrics 2002;110(5):e51.

2. De Cicco L, Schachner B, Giraudo N, et al. Implementación de un Sistema de Vigilancia Activa de Infecciones Intrahospitalarias en una Unidad de Cuidados Intensivos Pediátricos. Arch Argent Pediatr 2005;103(2):118-28.

3. Odetola FO, Moler FW, Dechert RE, et al. Nosocomial catheter-related bloodstream infections in a pediatric intensive care unit: risk and rates associated with various intravascular technologies. Pediatr Crit Care Med 2003 Oct;4(4):432-6.

4. McGeeDC, Gould MK.Preventing Complications of Central Venous Catheterization. NEngl JMed 2003;348(12):1123-33.

5. Pronovost P, Needham D, Berenholtz S, et al. An intervention to decrease catheter-related bloodstream infections in the UCI. N Engl J Med 2006;355(26):2725-32.

6. Costello JM, Morrow DF, Graham DA, et al Systematic intervention to reduce central line-associated bloodstream infection rates in a pediatric cardiac intensive care unit. Pediatrics 2008;121(5):915-23.

7. BerenholtzSM, Pronovost PA, Lipsett PA, et al. Eliminating catheter-related bloodstream infections in the intensive care unit. Crit Care Med 2004;32(10):2014-20.

8. Menegueti M, Ardison KM, Bellissimo-Rodrígues F, et al. The Impact of Implementation of Bundle to Reduce
Catheter-Related Bloodstream Infection Rates. J Clin Med Res 2015;7(11):857-61.

9. NNISSystem. National Nosocomial Infections Surveillance (NNIS) system report, data summary from January 1990May 1999, issued June 1999. A report from the NNIS System. Am J Infect Control 1999;27(6):520-32.

10. Coopersmith CM, Rebmann TL, Zack JE, et al. Effect of an education program on decreasing catheter-related bloodstream infections in the surgical intensive care unit. Crit Care Med 2002;30(1):59-64.

11. Curtis J, Cook DJ, Wall RJ. et al. Intensive care unit quality improvement: A "how to" guide for the interdisciplinary team. Crit Care Med 2006;34(1):211-8.

12. Pronovost P, Goeschel C, Colantuoni E, et al. Sustaining reductions in catheter related bloodstream infections in Michigan intensive care units: observational study. BMJ 2010;340:c309.

13. Pronovost PJ, Berenholtz SM, Needham DM. Translating evidence into practice: A model for large scale knowledge translation. BMJ 2008;337:a1714.

14. Hospital Garrahan. Vigilancia epidemiológica anual. Comunicación interna. 2010-2012.

15. Dudeck MA, Horan TC, Peterson KD, et al. National Healthcare Safety Network(NHSN) Report. DataSummary for 2009. Device Asociated Module. Am J Infect Control 2011;39(5):349-67.

16. Lenz AM, Latini B, Ruvinsky S. Programa de Prevención de Infecciones Asociadas a Catéteres en UCIP. In VIII Jornadas Multidisciplinarias Hospital Garrahan. 16-30 agosto de 2011; Buenos Aires.

17. Programa Nacional de Epidemiología y Control de Infecciones Hospitalarias (VIHDA). República Argentina. Ministerio de Salud. [Accessed on: August 22nd, 2017]. Available at: www.vihda.gov.ar.

18. Espiau M, Pujol M, Campins-Martí M, et al. Incidencia de bacteriemia asociada a catéter venoso central en una unidad de cuidados intensivos. An Pediatr (Barc) 2011;75(3):188-93.

19. Semelsberger, CF. Educational interventions to reduce the rate of central catheter-related bloodstream infections in the NICU: a review of the research literature. Neonatal Netw 2009;28(6):391-5.

20. Hong TS, Bush EC, Hauenstein MF, et al. A hand hygiene compliance check system: brief communication on a system to improve hand hygiene compliance in hospitals and reduce infection. J Med Syst 2015;39(6):69.

21. Gluyas H. Understanding non-compliance with hand hygiene practices. Nurs Stand 2015;29(35):40-6.

22. White KM, Jimmieson NL, Obst PL, et al. Using a theory of planned behaviour framework to explore hand hygiene beliefs at the ' 5 critical moments' among Australian hospital- based nurses. BMC Health Serv Res 2015;15:59. 


\section{ANNEX 1}

\section{Definitions}

The statistical measure used in this study was the rate of infections per $1000 \mathrm{CVC}$ days (recommended by the CDC). The formula was as follows:

CRI/1000 CVC days: Number of bacteremias in a specific period x 1000

Number of CVC days in the same specific period

Another statistical measure used here was the rate of CVC use. The formula was as follows:

Use rate: $\quad$ Number of CVC days in a specific period $\times 100$

Number of total length of stay in days in the same period 
ANNEX 2

Observation form of hand hygiene.

Implementation of the five moments at the point of patient care. Checklist

\begin{tabular}{|c|c|c|c|c|c|}
\hline \multicolumn{4}{|c|}{ OBSERVATION FORM OF HAND HYGIENE } & \multirow{2}{*}{$\begin{array}{l}\text { DATE } \\
\text { OBSERVED PROVIDER }\end{array}$} & \multirow{2}{*}{$I_{-}$} \\
\hline \multirow{2}{*}{ OBSERVER } & & & & & \\
\hline & & & & \multicolumn{2}{|l|}{ HOSPITALIZATION AREA } \\
\hline OCCASION & INDICATIONS & MODALITY & OCCASION & INDICATIONS & MODALITY \\
\hline & $\square$ Before touching a patient & \multirow{2}{*}{$\square$ Rubbing } & \multirow{5}{*}{2} & $\square$ Before touching a patient & \multirow{2}{*}{$\square$ Rubbing } \\
\hline & $\square$ Before aseptic procedure & & & $\square$ Before aseptic procedure & \\
\hline & $\square$ After body fluid exposure & \multirow{2}{*}{$\square$ Washing } & & $\square$ After body fluid exposure & \multirow{2}{*}{$\square$ Washing } \\
\hline & $\square$ After touching a patient & & & $\square$ After touching a patient & \\
\hline & $\begin{array}{l}\text { After touching patient } \\
\text { surroundings }\end{array}$ & $\square$ Not done & & $\begin{array}{l}\text { After touching patient } \\
\text { surroundings }\end{array}$ & $\square$ Not done \\
\hline OCCASION & INDICATIONS & MODALITY & OCCASION & INDICATIONS & MODALITY \\
\hline \multirow{5}{*}{3} & $\square$ Before touching a patient & \multirow{5}{*}{$\square$ Rubbing } & \multirow{5}{*}{4} & $\square$ Before touching a patient & \multirow{2}{*}{$\square$ Rubbing } \\
\hline & $\square$ Before aseptic procedure & & & $\square$ Before aseptic procedure & \\
\hline & $\square$ After body fluid exposure & & & $\square$ After body fluid exposure & \\
\hline & $\square$ After touching a patient & & & $\square$ After touching a patient & $g$ \\
\hline & $\begin{array}{l}\text { After touching patient } \\
\text { surroundings }\end{array}$ & & & $\begin{array}{l}\text { After touching patient } \\
\text { surroundings }\end{array}$ & $\square$ Not done \\
\hline OCCASION & INDICATIONS & MODALITY & OCCASION & INDICATIONS & MODALITY \\
\hline \multirow{5}{*}{5} & $\square$ Before touching a patient & \multirow{3}{*}{$\square$ Rubbing } & \multirow{5}{*}{6} & $\square$ Before touching a patient & \multirow{2}{*}{$\square$ Rubbing } \\
\hline & $\square$ Before aseptic procedure & & & $\square$ Before aseptic procedure & \\
\hline & After body fluid exposure & & & After body fluid exposure & \multirow{2}{*}{$\square$ Washing } \\
\hline & $\square$ After touching a patient & $\square$ Washing & & $\square$ After touching a patient & \\
\hline & $\begin{array}{l}\text { After touching patient } \\
\text { surroundings }\end{array}$ & $\square$ Not done & & $\begin{array}{l}\text { After touching patient } \\
\text { surroundings }\end{array}$ & \\
\hline OCCASION & INDICATIONS & MODALITY & OCCASION & INDICATIONS & MODALITY \\
\hline \multirow{5}{*}{7} & $\square$ Before touching a patient & \multirow{5}{*}{$\begin{array}{l}\square \text { Rubbing } \\
\square \text { Washing }\end{array}$} & \multirow{5}{*}{8} & $\square$ Before touching a patient & \multirow{4}{*}{$\square$ Rubbing } \\
\hline & $\square$ Before aseptic procedure & & & $\square$ Before aseptic procedure & \\
\hline & $\square$ After body fluid exposure & & & $\square$ After body fluid exposure & \\
\hline & $\square$ After touching a patient & & & $\square$ After touching a patient & \\
\hline & $\begin{array}{l}\text { After touching patient } \\
\text { surroundings }\end{array}$ & & & $\begin{array}{l}\square \text { After touching patient } \\
\text { surroundings }\end{array}$ & $\square$ Not done \\
\hline
\end{tabular}


ANNEX 3

CVC bundle of measures. CVC insertion checklist

\begin{tabular}{|c|c|c|c|c|c|c|c|c|c|c|}
\hline \multicolumn{11}{|l|}{ HOSPITAL: } \\
\hline $\begin{array}{c}\text { BUNDLE - CVC } \\
\text { Bundle of measures }\end{array}$ & \multicolumn{10}{|c|}{ CENTRAL VENOUS CATHETER INSERTION } \\
\hline \multicolumn{4}{|l|}{ DATE $」 」 \perp$} & \multicolumn{7}{|l|}{ ICU: } \\
\hline \multicolumn{4}{|l|}{ MEDICAL RECORD No.: } & \multicolumn{2}{|c|}{ OBSERVER } & \\
\hline \multirow{2}{*}{$\begin{array}{c}\text { OPERATOR } \\
\text { (the person inserting the CVC) } \\
\text { (INITIALS) }\end{array}$} & PHY & & & \multirow{2}{*}{\multicolumn{2}{|c|}{$\begin{array}{l}\text { ASSISTANT } \\
\text { (INITIALS) }\end{array}$}} & \multicolumn{2}{|c|}{ PHY } & & & \\
\hline & NUR & & & & & \multicolumn{2}{|c|}{ NUR } & & & \\
\hline \multicolumn{11}{|c|}{ 1-HAND HYGIENE } \\
\hline \multirow[b]{2}{*}{ OPERATOR } & M1 & \multicolumn{4}{|c|}{ BEFORE TOUCHING A PATIENT } & \multicolumn{2}{|c|}{ YES } & $\square$ & NO & $\square$ \\
\hline & M2 & \multicolumn{4}{|c|}{$\begin{array}{l}\text { BEFORE ASEPTIC PROCEDURE } \\
\text { (CVC insertion) }\end{array}$} & & YES & $\square$ & NO & $\square$ \\
\hline ASSISTANT & M1 & \multicolumn{4}{|c|}{ BEFORE TOUCHING A PATIENT } & & YES & $\square$ & NO & $\square$ \\
\hline \multicolumn{7}{|c|}{ 2- KIT OR TRAY CONTAINING ALL NECESSARY ELEMENTS FOR CVC INSERTION } & YES & $\square$ & NO & $\square$ \\
\hline \multicolumn{7}{|c|}{$\begin{array}{c}\text { 3- ADEQUATE ANTISEPSIS AT THE INSERTION SITE: } \\
* 2 \% \text { CHLORHEXIDINE SOLUTION OR ALCOHOL-BASED CHLORHEXIDINE }\end{array}$} & YES & $\square$ & NO & $\square$ \\
\hline \multicolumn{7}{|c|}{ * APPLIED ON THE SKIN BY RUBBING FOR AT LEAST 30 SECONDS AND NOT MORE THAN 2 MINUTES } & YES & $\square$ & NO & $\square$ \\
\hline \multicolumn{7}{|c|}{$\begin{array}{l}\text { * WAITING TIME (1-2 minutes approximately) TO LET THE ANTISEPTIC SOLUTION DRY OFF BEFORE } \\
\text { PRICKING THE SKIN }\end{array}$} & YES & $\square$ & NO & $\square$ \\
\hline \multicolumn{7}{|c|}{$\begin{array}{l}\text { 4- USE OF MAXIMAL BARRIER PRECAUTIONS: } \\
\text { FOR THE PATIENT: COMPLETE COVERAGE USING A STERILE FIELD OR LARGE COMPRESS }\end{array}$} & YES & $\square$ & NO & $\square$ \\
\hline \multirow{3}{*}{$\begin{array}{l}\text { WEARING A STERILE GOWN } \\
\text { OPERATOR }\end{array}$} & 5- USE & $M A$ & BARRIER PRECAUTION & FOR TH & RATO & & \multirow[b]{2}{*}{$\square$} & & & \\
\hline & YES & $\square$ & \multirow{2}{*}{\multicolumn{2}{|c|}{$\begin{array}{c}\text { WEARING A STERILE GOWN } \\
\text { ASSISTANT }\end{array}$}} & YES & & & & MENTS & \\
\hline & NO & $\square$ & & & NO & & $\square$ & & & \\
\hline WEARING A HAT & YES & $\square$ & WEARING A HA & & YES & & $\square$ & & MENTS & \\
\hline OPERATOR & NO & $\square$ & ASSISTANT & & NO & & $\square$ & & & \\
\hline WEARING A MASK & YES & $\square$ & WEARING A MA & & YES & & $\square$ & & MENTS & \\
\hline OPERATOR & NO & $\bar{\square}$ & ASSISTANT & & NO & & $\square$ & & & \\
\hline WEARING STERILE GLOVES & YES & $\square$ & WEARING STERILE G & JVES & YES & & $\square$ & & MENTS & \\
\hline OPERATOR & NO & $\square$ & ASSISTANT & & NO & & $\square$ & & & \\
\hline
\end{tabular}


ANNEX 4

\section{Activities done during the program}

Measures

1. Surveillance program

\section{Training program}

a. Talks to train the nurses from each working shift (especially newcomers), medical staff, shift supervisors, and the nurses' supervisor on the new bundle of measures recommended to prevent catheter-related infections at the ICU held every 6 months.

b. Information posters designed for health care staff and placed inside the ICU.

c. Information posters designed for parents on hygiene measures placed on the ICU door.

d. Alcohol gel or chlorhexidine solution available in each ICU.

\section{Pharmacy Department}

\section{Link nurse ${ }^{*}$}

3. Catheter insertion and management protocol

a. Central venous catheter insertion technique: barriers for

CVC insertion include wearing a sterile hat, mask, gown, gloves and using a sterile field in a pre-assembled kit with a checklist and respecting waiting times when applying a specific antiseptic solution ( $2 \%$ chlorhexidine or other) and achieving their maximum effect before CVC insertion.

b. The CVC should not be routinely replaced at pre-established intervals.

c. CVC replacement using the Seldinger technique will only be done if there is no infection at the insertion site or catheter-related bacteremia in that position and only in exceptional cases.

d. Daily discussion of CVC requirements: catheter use should not be unnecessarily prolonged.
Responsible party Department of Infectious Diseases and Epidemiology

Nurses' supervisor together with the shift supervisors

Department of Infectious Diseases and Epidemiology

Department of Infectious Diseases and Epidemiology

Department of Infectious Diseases and Epidemiology

Department of Infectious Diseases and Epidemiology

\author{
Medical staff \\ Link nurse \\ Other members of the health care team
}

4. Central venous catheter use and care

- The CVC insertion site should be protected with a sterile, transparent, semi-permeable or permeable dressing or a dry gauze pad.

- The protection system should only be changed if dirty or wet.

- Insertion site care should be done based on local assessment or every 7 days.

- The plugs of the three-way stopcock should be cleaned with an alcohol-soaked gauze for 15 seconds before accessing infusion systems.

- It is necessary to check for cracks or leaks in the infusion system and keep the circuit closed when not in use.

\author{
Medical staff \\ Link nurse \\ Other members of the health care team \\ Medical staff \\ Link nurse \\ Other members of the health care team \\ Medical staff \\ Link nurse \\ Other members of the health care team
}

* Link nurse: ICU nurse who does not take patients under his/her charge and who acts as infection monitoring nurse at the ICU during his/her whole shift.

Medical staff

Link nurse

Shift supervisor

Other members of the health care team 


\section{Program implementation stages}

Program stages

Stage I: Historical control

Stage II: Intervention design and implementation
August 2010-May 2011. Prior statistics from each participating site.

- Training and education of selected staff members (a nurse and a physician) from each participating ICU for the implementation of the program by the coordinating site.

- Delivery of a CD containing all tools (instructions, forms) necessary to implement the program.

- Health care staff training by the staff members who were trained by the coordinating site.

- Uploading a site to the coordinating hospital's online campus with all the necessary information and providing guidance through this site.

- Implementation of hand hygiene and CVC insertion checklists.

- Monitoring adherence to hand hygiene, CVC insertion, and bacteremia statistics at each ICU using the corresponding forms for each activity. 